\title{
An Open label retrospective, controlled study to evaluate efficacy of Sinhyadi ghrita in the management of Balsosha with special reference to undernutrition
}

\author{
Research Article
}

\author{
Rajkumar Harinkhede ${ }^{1^{*}}$, Chavan DB ${ }^{2}$, Gawai VU ${ }^{3}$, Minakshi Patle ${ }^{4}$ \\ 1. PG Scholar, 2. Guide \& Associate Professor, 3. Professor \\ Department of Kaumarabhritya, Govt. Ayurved College, Nanded, Maharashtra \\ 4. Intern. M.S. Ayurved College Gondia, Maharashtra
}

\begin{abstract}
Balshosha which can be correlated with undernutrition (P.E.M.) is one of such disease occurring in children due to hampered nutrition or dhatuposhana. Nutrition is necessary for maintaining growth, the effect of nutrition reflects on development. Today nutrition deficiency constitutes a major public health problem in India. The goal of treatment is to be provided adequate calories for dual purpose, to replace losses and build up nutrition to promote growth. HPERM is indicated for home remedial treatment for mild to moderate PEM (Undernutrition / Malnutrition) however condition needs to be medically intervented to prevent the worsening of the situation and to provide adequate correction. Sinhyadi Ghrita mentioned in A shtanghridya by Vagbhata is best in balshosha. Hence an attempt was made to study the effect of sinhyadi ghrita in the management of Balshosha(undernutrition).In present study two groups containing 30 patients each suffering from undernutrition were selected randomly irrespective to sex, gestational age. Sinhyadi ghrita and HPERM combination was used as a trial group. Parameters such as weight, height, MUAC, skin elasticity, BMI, dehabla, agnibala were taken in to consideration for assessing results. At the end of study it was found that trial drug was very effective in the management of undernutrition.
\end{abstract}

Keywords: Balasosha, Sinhyadi Ghrita, undernutrition, HPERM, PEM, Dehabala, Agnibala

\section{Introduction}

Equilibrium of doshas and freedom from all the disease is health for this purpose the sages studied the sacred Ayurveda. Kaumarbhritya is a branch of Ashtang Ayuveda deals with the management of children beginning from procreation; Ayurveda lays upmost importance to Kaumarbhritya because this age is determining how the person should become later on in his life(1),(2),(3). Balshosha which can be correlated with undernutrition is one of such disease occurring in children due to hampered nutrition or dhatuposhana. Nutrition is necessary for maintaining growth, the effect of nutrition reflects on development. Today nutrition deficiency constitutes a major public health problem in India.

India is one of the fastest growing countries in terms of population and economics, sitting at a population of 1,139.96 million (2009) and growing at $10-14 \%$ annually (from 2001-2007). Since Independence in 1947, its economic status has been classified as a low-income country with majority of the population at or below the poverty line. The combination of people living in poverty and the recent economic growth of India has led to the co-emergence of undernutrition.

*Corresponding Author:

Rajkumar Harinkhede,

PG Scholar, Department Of Kaumarbhritya

Govt. Ayurved College

Nanded, Maharashtra.

Email Id: dr.rcharinkhede@gmail.com
According to recently released National Family Health Survey NFHS-3 carried out in 2005-2006, 40\% of India's children under the age of three year are underweight, $45 \%$ are stunted and $23 \%$ are wasted. Proportion of children who are stunted or underweight increases rapidly with child age(4).

Undernutrition includes both protein-energy malnutrition and micronutrient deficiencies. Undernourishment not only affects physical appearance and energy levels, but also directly affects many aspects of the children's mental functions, growth and development which have adverse effects on their ability to learn and process information thereby leading to nonproductive and non-contributing members of society. Child malnutrition is responsible for 22 percent of India's burden of disease. The prevalence of underweight children in India is among the highest in the world. The World Bank estimates that India ranks $2^{\text {nd }}$ in the world for the number of children suffering from malnutrition after Bangladesh (in 1998), where $47 \%$ of the children exhibit a degree of malnutrition. ${ }^{[5]}$

Malnutrition increases the risk of infections and infectious disease; for example, it is a major risk factor in the onset of active tuberculosis. In communities or areas that lack access to safe drinking water, these additional health risks present a critical problem. Lower energy and impaired functions of the brain also represent the downward spiral of malnutrition as victims are less able to perform the tasks they need to in order to acquire food, earn an income, or gain an education.

The goal of treatment is to be provided adequate calories for dual purpose, to replace losses and 
build up nutrition to promote growth. Hyderabad Protein Energy Rich Mixture(HPERM) is indicated for home remedial treatment for mild to moderate PEM (Undernutrition / Malnutrition) however condition needs to be medically intervened to prevent the worsening of the situation and to provide adequate correction(6),(7),(8).

Due excessive sleeping during day time, excess consumption of cold water and breast milk vitiated by kapha, etc. Cause the dushti of kapha and vata, dushit kapha along with vata blocks the entire channel nourishing the rasa, raktadi dhatus. Due to obstruction of strotasas, dhatvarhayas which is needed nourishment of dhatus is unable to reach them which leads to their kshayas.

As food is not properly digested it fails to nourish all the body results in emaciation.

As the disease is strotorodhjanya with predominance of kapha, the treatment should be strotoshodhan. Balshosha is disease related with dhatu and its nourishment. Hence the treatment should be aimed at agitation of jatharagni i.e. deepan pachan along with proper nourishment i.e. brimhana.

Sinhyadi Ghrita mentioned in Ashtanghridya by Vagbhata is best in balshosha. Hence an attempt was made to study the effect of sinhyadi ghrita in the management of Balshosha (undernutrition). Kantkari, ashwagandha, tulsi, pippali these drug mentioned by ashtang hridya in sinhyadi ghrita is the best in the management of balshosha. It relieves strotorodh and helps in dhatu poshan and its deepan pachan properties it ignite jathragni.(9)

\section{Materials and Methods}

For the clinical study of sinhyadi ghrita, patient suffering from undernutrition were selected from O.P.D. and I.P.D. of kaumarbhritya Department.

\section{Materials of Study:}

Patients.

Sinhyadi Ghrita

HPERM.

The materials of Sinhyadi Ghrita and HPERM were purchased from local market.

\section{Clinical Study:}

Before initiation of the study, study protocol and related documents were reviewed and approved by institutional ethics committee at Government Ayurved College, Nanded, Maharashtra, India.

Ethical clearance no- GACN/IEC/124/2014/ dated$15 / 04 / 2014$

\section{Study Designs:}

Randomized perspective controlled clinical study.

60 patients was selected and randomly grouped into two for trial and control group.

Procedure for administration of drug:

Trial Group:

Sinhyadi Ghrita was given with HPERM.

Sinhyadi Ghrita was given as per young's formula. ${ }^{[10]}$

Young's formula as follow:

Child dose $=$ Age in yrs $\times$ adult dose

Age +12

HPERM was given as per energy and protein requirements of children(11) according to their age. Both were given for duration of 12 weeks in divided doses.

\section{Control Group:}

Only HPERM was given as per energy and protein requirement of children according to their age for duration of 12 weeks in divided doses.

Energy and Protein Requirement:(11)

(According to National Institute of Nutrition, Hyderabad)

$\begin{array}{cccc}\text { Particulars } & \begin{array}{c}\text { Body } \\ \text { weight } \\ \text { (kg) }\end{array} & \begin{array}{c}\text { Energy } \\ \text { (Kcal/ } \\ \text { day) }\end{array} & \begin{array}{c}\text { Protein } \\ \text { (gm/day) }\end{array} \\ \text { 1-3 Years } & 12.2 & 1240 & 22 \\ \text { 3-6 Years } & 19 & 1690 & 30\end{array}$

Preparation of Sinhyadi Ghrita(12):

First Ghrita Murchhana is carried out. So the $1 \mathrm{~kg}$ Bharada Churna(not fine powder) of kantkari, ashwagandha, pippali, tulsi and 4 litre Goghrita and 16 litre drinking water are taken. The ingredients are mixed, then mixture was kept for boiling with continuous stirring. Mandagni is given to mixture. The mixture boiled until the appearance of sneha siddhi laksana. When water gets evaporated completely, the heating was stopped. Then it is allowed to cool room temperature, then it was filtered to get sinhyadi ghrita.

\section{Standardization of Drugs:}

Standardization of the drugs under trial was done at central Govt. certified Laboratory.

The physio-chemical values of sinhyadi ghrita are as follows

$\begin{array}{ccc}\text { Sr.No } & \text { Parameter } & \text { Result } \\ 1 & \text { Moisture } & 0.19 \% \\ 2 & \mathrm{Ph} & 6.50 \\ 3 & \text { Total Mineral } & 0.45 \% \\ 4 & \text { Fat } & 92.94 \% \\ 5 & \text { Protein } & 0.02 \% \\ 6 & \text { Carbohydrate } & 3.76 \% \\ 7 & \text { Energy } & 851 \mathrm{Kcal}\end{array}$


Dose:

In Sharangadhara Samhita (Madhyama Khanda, Sneha Kalpana Adhyaya) various sneha kalpa are mentioned. Its dose is given as 1 pala $(40 \mathrm{ml})$ per day in adults.

So, according to age average value dose was decided and given in two divided doses.

$\begin{array}{cc}\text { AGE (year) } & \text { DOSE }(\mathbf{m l}) / \mathbf{d a y} \\ 1 & 4 \\ 2 & 6 \\ 3 & 8 \\ 4 & 10 \\ 5 & 12\end{array}$

\section{Aushadha Sevana Kala:}

The time of Drug taken was Adhobhakta (Bhojanottara) According to Ashtanga Sangraha the drug should be taken immediately after meals for for Brimhana Karma. So, in this present study according to the above reference the time was taken bhojanottara for brimhana effect.(13)

\section{Hyderabad Protein Energy Rich Mixture(HPERM):}

National institute of Hyderabad has given protein - energy rich mixture formula for home treatment of undernutrition which was taken in this present study to see its brimhana effect in balshoshaMild to Moderate Malnourished 1-6 years aged children.

\section{The formula is :}

$\begin{array}{ll}\text { Roasted whole wheat } & 40 \mathrm{~g} \\ \text { Roasted Bengal gram } & 16 \mathrm{~g} \\ \text { Roasted groundnut } & 10 \mathrm{~g} \\ \text { Jaggery } & 20 \mathrm{~g} \\ \text { Total } & 86 \mathrm{~g}, \text { providing } 330 \\ & \mathrm{kcal} \text { and } 11.3 \mathrm{~g} \text { proteins }\end{array}$

HPERM was given in a accordance to WHO and National Institute of Nutrition, Hyderabad recommendation of energy and protein requirement of children according to their age for a duration of 12 weeks in divided doses.(14)

\section{Observation Period:}

Study period: 12 weeks (90 days)

Follow ups: Assessment on $0-30^{\text {th }}-60^{\text {th }}$ and $90^{\text {th }}$ days.

Inclusion Criteria:

Children age between 1- 5 Yrs.

Children evaluated with grade I \& II Protein Energy Malnutrition(PEM) according to Indian Academy of Pediatrics(IAP) Classification(15)

Children should be free from any systemic or surgical illness.

\section{Exclusion Criteria:}

Children of age below $1 \mathrm{yr}$ and above 5 years.

Severely malnourished children (Grade III and IV PEM according to I.A.P. classification)
Any medical emergency or condition requiring Dropout: surgical intervention.

If children having complications during treatment and who were not co-operative, lack of regular follow ups were dropped out.

\section{Diagnostic Criteria:}

Weight for age

Body mass Index (B.M.I.)

Mid upper arm circumference

Skin fold thickness

Criteria for Assessment and Result:

Objective

Weight

Height

Mid arm circumference

Skin fold thickness

B.M.I.

Subjective

Hair pigmentation

Skin elasticity

Agnibala

Dehabala

Overall Assessment: Deficient weight for age before treatment was considered as $100 \%$ and weight was assessed accordingly,

Less than $25 \%$ - low

$26 \%$ to $50 \%$ - mild

$51 \%$ to $75 \%$ - moderate

More than $75 \%$ - good

\section{Hair Pigmentation:}

Particulars

Score

Normal hairs

Hypopigmentation at the tip of hairs

Hypopigmented hairs involving $2 / 3^{\text {rd }}$ length of hairs

Small areas of scalp showing

hypopigmented hairs

Alternate bands of normal and small hypopigmented hairs (flag sign)

\section{Skin Elasticity:}

\section{Particulars}

Score

Normal skin turgor

Loose skin with some fat when pinched and released return to normal slowly

taking 2-3 seconds

Loose skin when pinched and released returned to normal very slowly taking few seconds

Thin, loose, wrinkled skin 
Agnibala (Abhyavaran Shakti):

\begin{tabular}{|l|c|}
\hline \multicolumn{1}{|c|}{ Particulars } & Score \\
\hline $\begin{array}{l}\text { Taking food in good quantity twice / thrice } \\
\text { a day }\end{array}$ & 0 \\
\hline Taking food moderate quantity twice a day & 1 \\
\hline Taking food in less quantity twice a day & 2 \\
\hline Child not taking food at all & 3 \\
\hline
\end{tabular}

Dehabala- Swar(Texture) Varna(Lusture) and Yoga (voice):

\begin{tabular}{|l|c|}
\hline \multicolumn{1}{|c|}{ Particulars } & Score \\
\hline Patient look cheerful & 0 \\
\hline Lethargic and tired & 1 \\
\hline Patient looks gloomy & 2 \\
\hline
\end{tabular}

\section{Discussion:}

Balshosha (Child malnutrition) is responsible for 22 percent of India's burden of disease. The prevalence of underweight children in India is one of the highest among the world. Balshosha which can be correlated to undernutrition (PEM) of modern science is one of such disease i.e. occurring in children due to hampered nutrition or dhatuposhana. This disease has been described in detail by Acharya Vagbhata only, but other conditions that are similar with the signs and symptoms of phakka, karshya, gatrasosha, etc.,are described in almost all samhitas. Regarding to samprapti of balshosha, there are two main entities i.e. vata-kapha prakopa and strotorodha, which ultimately leads to improper nutrition and emaciation of dhatu.

WHO has described malnutrition as a "global problem", having adverse effects on the survival, health, performance and progress of populating groups. The most significant preventive measures for this disease is "nutritional education" which includes good antenatal care, encouraging mothers for regular breast feeding, complementary feeding, supplements should be the combination of cereals, protein-rich foods and fruits, National Nutrition Programs, etc.

The goal of treatment is to provide adequate calories for dual purpose to replace the losses and build up nutrition to promote growth. HPERM is indicated for home remedial treatment for mild to moderate PEM (Undernutrition / Malnutrition), however condition needs to be medically intervened to prevent the worsening of the situation and to provide adequate correction.

Sinhyadi Ghrita mentioned in Ashtanghridya by Vagbhata is the best in balshosha. Sinhyadi ghrita contains kantakari, ashwagandha, tulsi, pippali and ghrita. All these drugs are well known for their srotoshodhana and brimhana karma. These drugs help in improving digestion and increase the appetite by agitating the jathragni and help to maintain nutrition of the body and weight gain. (17)(18)(19)

For this present study, children from the age of
1 year to 5 year of either sex with the problem of poor growth \& under development and without any chronic diseases, systemic disorders, congenital anomalies, neurological disorders, endocrine disorders, anatomical defects were included. Simple Random Multiphase Sampling Method was adopted for this present study. According to IAP classification of PEM, children of body weight $61-80 \%$ of expected weight for age i.e. grade - I \& II were selected for this study. For Average weight the chart of I.C.M.R. - Average weight of boys and girls at different ages for Indian children was used. (20)

In religion wise distribution, patients were selected from the Hindu and Muslim religions of the society. Maximum number of patients was Hindu i.e. $96.66 \%$ in experimental group and $93.33 \%$ in control group. As in Muslim community there is more intake of non-vegetarian diet so there is less percentage of balshosha.

In socio-economic status wise distribution patients were selected randomly from poor and middle classes, maximum number of patients were from poor class i.e $63.33 \%$ in experimental group and $53.33 \%$ in control group. Children from Poor class are more prone to undernutrition.

Grade wise distribution of patients of malnutrition, it was found that maximum number of patients of grade -II i.e. $60 \%$, and patients of grade -i.e. $40 \%$.

The assessment of nutritional status was done on the basis of anthropometric measurements with the help of weighing machine, measuring tape and skin fold callipers and subjective parameters as mentioned earlier.

As far as Agni is concerned, it is very difficult to assess the status of Agni in patient of paediatric age group. It is assessed by abhyavarana and jarana Shakti of patients.

Patients were advised to give regular follow up. In successive follow up they were observed every 30 days. Nine patients were dropped out during the study due to irregular follow up. After complete follow up, results in objective and subjective parameter were recorded and analyzed statistically. This is explained in detail in chapter observation and results.

This study requires further research in order to study for its better effects of ayurvedic remedies on balsosha. Further research can be carried out by the increasing duration of treatment and remodelling the dose, according to the age and weight of the patients.

Statistical analysis showed there was a significant improvement in weight, height, mid arm circumference, skin fold thickness, body mass index, hair pigmentation, skin elasticity, agnibala, dehabala in both the groups. But trial group showed overall better results as compared to control group.

\section{Conclusion:}

Balshosha (undernutrtion) is more common in India and it is the most common cause of morbidity and mortality.

Most of the patients of balshosha are between the ages of 1-3 years and male and female are equally affected by balshosha. 
Patients suffering from Grade II malnutrition are more as compared to patients suffering from grade I malnutrition.

It is a scenario of our India that due to poverty, population and unemployment many people do not get food properly in quantity as well as quality. So, due to lack of proper nourishment, most of the poor children are more affected to balshosha.

In developing country like India, many children are suffering with balshosha. So, this study will be the largest research topic in future. Large sample will make better conclusion and less bias.

Statistical analysis showed that there is significant improvement in weight, height, mid upper arm circumference, skin fold thickness, body mass index, hair pigmentation, skin elasticity, agnibala, dehabala in both groups. But trial group shows overall better results as compare to control group.

It concluded that comparison between trial and control groups, showed insignificant results on most of the parameters. This may be due to around same, mean score found in both groups. It means that the result of control group was as good as the results of trial group. Trial Group shows better results individually.

\section{References}

1. Kashyapsamhita - with vidyotini Hindi commentary by Shri Satyapal Bhishgacharya. Published by Chaukhambha Bharati Academy, Varanasi, reprinted in 2006.

2. Charak Samhita - Srimad Agnivesha Aacharya pranita Charak - Dradhabala pratisanskrita "“ Vidhyotini " Hindi Vyakhyopeta Part-I Vyakhyakruta by Pandit Kashinatha Pandeya \& Dr. Gorakhanath Chaturvedi which Published by Chaukhambha Bharati Academy, Varanasi, reprinted in 2008.

3. Sushruta Samhita -- Text with English Translation By Kaviraj Kunjalal Bhishagratna Prologued \& Edited by Dr. Jyotir Mitra Publication by Chaukhambha Sanskrit Series Office, Varanasi Vol. I, third edition, printed in 2005 \& Vol. 2, third edition printed in 2007.

4. Ghai Essential Pediatrics- Vinod K Paul, Arvind Bagga, Eighth Edition Reprinted 2014 By CBC Publishers And Distribution Pvt. Ltd.

5. Nelson textbook of Pediatrics - Robert M. Kliegman, MD, Nineteenth Edition Reprinted 2014 by Elsevier India Private Ltd. New Delhi

6. The Short Textbook of Pediatrics - Suraj Gupte 2009 , Eleventh Edition 2009, Published by
Jaypee Brothers Medical Publishers (P) Ltd, New Delhi

7. Gupte S. Marasmus and kwashiorkor, Pediatrics 1975; 56: 152-153.

8. Gupte S. Perspectives in infant nutrition. In Gupte S (Ed): Newer Horizons in Tropical Pediatrics $2^{\text {nd }}$ Edition, New Delhi, Jaypee 1986, 206-243.

9. Astanga Hridaya of Srimad Vagbhata Edited with , Nirmala Hindi Commentary alongwith special deliberation by Dr. Brahmanand Tripathi Publication by Chaukhambha Sanskrit Pratisthan, Delhi, reprinted in 2007.

10. Kaumarbhritya by Dr. Ayodhya Prasad Achal Published by Chaukhambha Surbharati Prakashan, Varanasi, reprinted edition in 2002 Young's rule P- 234

11. Dietary guidelines for Indians A Manual by National Institute of Nutrition, Hyderabad, second edition 2010 .

12. Sharangadhara Samhita of Pandita Sharangadharacharya containing , Anjananidana'e of Maharshi Agnivesha Annoted with „Dipika "Hindi Commentary by Dr. Brahmanand Tripathi; publication by Chaukhambha Surbharati Prakashan,Varanasi, Reprint 2010.

13. Astanga Sangraha - Hindi Vyakhya of Kaviraj Atridev Gupt Published by Chaukhambha Krishnadas Academy, Varanasi, reprinted in 2005 in Vol. I \& II.

14. Bulletin of the world health organization 57 (1): Pg.65-79 (1979)

15. IAP textbook of Pediatrics - Nutrition subcommittee of the Indian Academy of Pediatrics ( Std. Value - Nutritional grade )

16. B.K.Mahajan, Methods in Biostatistics, 6th Edition, Delhi, Jaypee Brothers medical Publishers, 2006.

17. Indian Council of Medical Research, Recommended Dietry Intakes for Indians, New Delhi : ICMR 1990.

18. Rajnighantu of Pandit Narahari Edited with "Dravyagunaprakashika", Hindi Commentary by Dr. Indradeo Tripathi Introduction by Acharya Viswanatha Dwivedi Publication by Krishnadas Academy, Varanasi, Second Edition, 1998.

19. Dravyaguna Vigyana Vol. II Vegetable Drugs by Prof. P.V. Sharma published by Chaukhambha Bharati Academy, Varanasi, Reprint 2005.

20. Shaligrama Nighantu Bhushanam (Bruhad Nighantu Ratnakarantargata 7-8 part ). 
Table No.1 Effect of Therapy on Weight

\begin{tabular}{|c|c|c|c|c|c|c|c|}
\hline \multirow{2}{*}{ Gr. } & \multicolumn{2}{|c|}{ T.Gr. } & \multicolumn{2}{c|}{ C.Gr. } & \multirow{2}{*}{ t calc. } & \multirow{2}{*}{ t table } & \multirow{2}{*}{ P } \\
\cline { 2 - 5 } & MEAN & S.D. & MEAN & S.D. & & & \\
\hline B.T. & 9.97 & 2.03 & 10.51 & 2.08 & 16.26 & 2.05 & $<0.05$ \\
\hline A.T. & 11.32 & 1.91 & 11.70 & 2.11 & 16.18 & 2.05 & $<0.05$ \\
\hline
\end{tabular}

Table No.2 Effect of Therapy on Height

\begin{tabular}{|c|c|c|c|c|c|c|c|}
\hline \multirow[t]{2}{*}{ GROUP } & \multicolumn{2}{|c|}{ T.Gr. } & \multicolumn{2}{|c|}{ C.Gr. } & \multirow{2}{*}{ t calc. } & \multirow{2}{*}{ t table } & \multirow{2}{*}{$\mathbf{P}$} \\
\hline & MEAN & S.D. & MEAN & S.D. & & & \\
\hline B.T. & 84.83 & 12.23 & 85.30 & 11.47 & 16.00 & 2.05 & $<0.05$ \\
\hline A.T. & 85.90 & 12.10 & 86.23 & 11.20 & 9.81 & 2.05 & $<0.05$ \\
\hline
\end{tabular}

Table No.3 Effect of Therapy on M.U.A.C

\begin{tabular}{|c|c|c|c|c|c|c|c|}
\hline \multirow{2}{*}{ GROUP } & \multicolumn{2}{|c|}{ T.Gr. } & \multicolumn{2}{c|}{ C.Gr. } & \multirow{2}{*}{ t calc. } & \multirow{2}{*}{ t table } & \multirow{2}{*}{ P } \\
\cline { 2 - 5 } & MEAN & S.D. & MEAN & S.D. & & & \\
\hline B.T. & 13.23 & 0.81 & 13.33 & 0.95 & 5.76 & 2.05 & $<0.05$ \\
\hline A.T & 13.62 & 0.71 & 13.55 & 0.82 & 4.17 & 2.05 & $<0.05$ \\
\hline
\end{tabular}

Table No.4 Effect of Therapy on S.F.T.

\begin{tabular}{|c|c|c|c|c|c|c|c|}
\hline \multirow{2}{*}{ GROUP } & \multicolumn{2}{|c|}{ T.Gr. } & \multicolumn{2}{c|}{ C.Gr. } & \multirow{2}{*}{ t calc. } & t & \multirow{2}{*}{ P } \\
\cline { 2 - 5 } & MEAN & S.D. & MEAN & S.D. & & & \\
\hline B.T. & 8.85 & 1.14 & 9.15 & 1.05 & 8.36 & 2.05 & $<0.05$ \\
\hline A.T & 9.21 & 1.08 & 9.45 & 0.91 & 4.44 & 2.05 & $<0.05$ \\
\hline
\end{tabular}

Table No.5 Effect of Therapy on H.C.

\begin{tabular}{|c|c|c|c|c|c|c|c|}
\hline \multirow{2}{*}{ GROUP } & \multicolumn{2}{|c|}{ T.Gr. } & \multicolumn{2}{c|}{ C.Gr. } & \multirow{2}{*}{ t calc. } & \multirow{2}{*}{ t table } & \multirow{2}{*}{ P } \\
\cline { 2 - 5 } & MEAN & S.D. & MEAN & S.D. & & & \\
\hline B.T. & 45.80 & 2.63 & 45.33 & 1.74 & 2.02 & 2.05 & $<0.05$ \\
\hline A.T. & 45.90 & 2.42 & 45.40 & 1.73 & 1.68 & 2.05 & $<0.05$ \\
\hline
\end{tabular}

Table No.6 Effect of Therapy on C.C.

\begin{tabular}{|c|c|c|c|c|c|c|c|}
\hline \multirow{2}{*}{ GROUP } & \multicolumn{2}{|c|}{ T.Gr. } & \multicolumn{2}{c|}{ C.Gr. } & \multirow{2}{*}{ t calc. } & \multirow{2}{*}{ t table } & \multirow{2}{*}{ P } \\
\cline { 2 - 5 } & MEAN & S.D. & MEAN & S.D. & & & \\
\hline B.T. & 47.50 & 4.16 & 46.83 & 2.42 & 2.79 & 2.05 & $<0.05$ \\
\hline A.T. & 47.68 & 4.00 & 47.17 & 2.46 & 3.80 & 2.05 & $<0.05$ \\
\hline
\end{tabular}

Table No.7 Effect of Therapy on Hair Pigmentation

\begin{tabular}{|c|c|c|c|c|c|c|}
\hline \multirow{2}{*}{ GROUP } & \multicolumn{2}{|c|}{ T.Gr. } & \multicolumn{2}{c|}{ C.Gr. } & \multirow{2}{*}{ Z Value } & \multirow{2}{*}{ P } \\
\cline { 2 - 5 } & MEAN & S.D. & MEAN & S.D. & & $<0.05$ \\
\hline B.T. & 1.20 & 0.71 & 1.03 & 0.80 & 4.1973 & $<0.05$ \\
\hline A.T. & 0.43 & 0.56 & 0.63 & 0.55 & 2.9341 & $<$ \\
\hline
\end{tabular}


Table No.8 Effect of Therapy on Skin Elasticity

\begin{tabular}{|c|c|c|c|c|c|c|}
\hline \multirow{2}{*}{ GROUP } & \multicolumn{2}{|c|}{ T.Gr. } & \multicolumn{2}{c|}{ C.Gr. } & \multirow{2}{*}{ Z Value } & \multirow{2}{*}{ P } \\
\cline { 2 - 5 } & MEAN & S.D. & MEAN & S.D. & & $<0.05$ \\
\hline B.T. & 1.40 & 0.56 & 1.03 & 0.55 & 4.4573 & $<0.05$ \\
\hline A.T. & 0.50 & 0.57 & 0.70 & 0.46 & 2.8031 & $<$ \\
\hline
\end{tabular}

Table No.9 Effect of Therapy on Agnibala

\begin{tabular}{|c|c|c|c|c|c|c|}
\hline \multirow{2}{*}{ GROUP } & \multicolumn{2}{|c|}{ T Gr. } & \multicolumn{2}{c|}{ C.Gr. } & \multirow{2}{*}{ Z } & \multirow{2}{*}{ P } \\
\cline { 2 - 5 } & MEAN & S.D. & MEAN & S.D. & & \\
\hline B.T. & 1.76 & 0.43 & 1.53 & 0.57 & 4.5407 & $<0.05$ \\
\hline A.T. & 0.80 & 0.48 & 0.90 & 0.40 & 3.8230 & $<0.05$ \\
\hline
\end{tabular}

Table No.10 Effect of Therapy on Dehabala

\begin{tabular}{|c|c|c|c|c|c|c|}
\hline \multirow{2}{*}{ GROUP } & \multicolumn{2}{|c|}{ T.Gr. } & \multicolumn{2}{c|}{ C.Gr. } & \multirow{2}{*}{ Z } & \multirow{2}{*}{ P } \\
\cline { 2 - 5 } & MEAN & S.D. & MEAN & S.D. & & $<0.05$ \\
\hline B.T. & 0.80 & 0.40 & 0.80 & 0.41 & 3.1798 & $<0.05$ \\
\hline A.T. & 0.36 & 0.49 & 0.63 & 0.49 & 2.0226 & \\
\hline
\end{tabular}

TABLE NO.11 Overall Assessment According To Weight

\begin{tabular}{|c|c|c|c|c|c|c|}
\hline $\begin{array}{c}\text { IMPROVE } \\
\text { MENT }\end{array}$ & LOW (<25\%) & $\begin{array}{c}\text { MILD (25 } \\
\mathbf{5 0 \% )}\end{array}$ & $\begin{array}{c}\text { MOD. (50- } \\
\mathbf{7 5 \% )}\end{array}$ & GOOD (>75\%) & $\chi^{\mathbf{2} \text { Calc. }}$ & P \\
\hline T.Gr. & 5 & 11 & 12 & 2 & \multirow{2}{*}{1.84} & \multirow{2}{*}{0.6} \\
\hline C.Gr. & 6 & 15 & 8 & 1 & & \\
\hline
\end{tabular}

Graph no.1

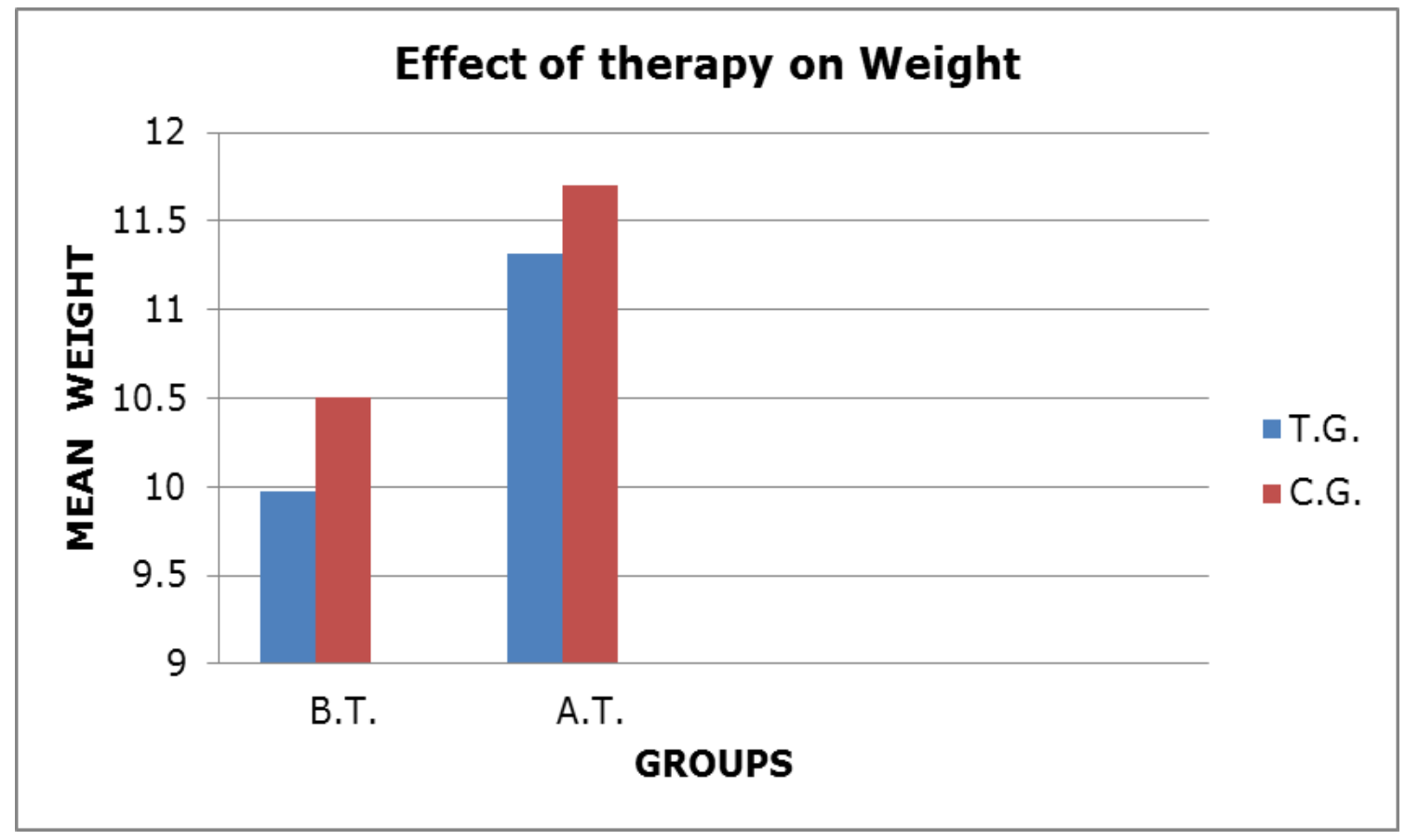




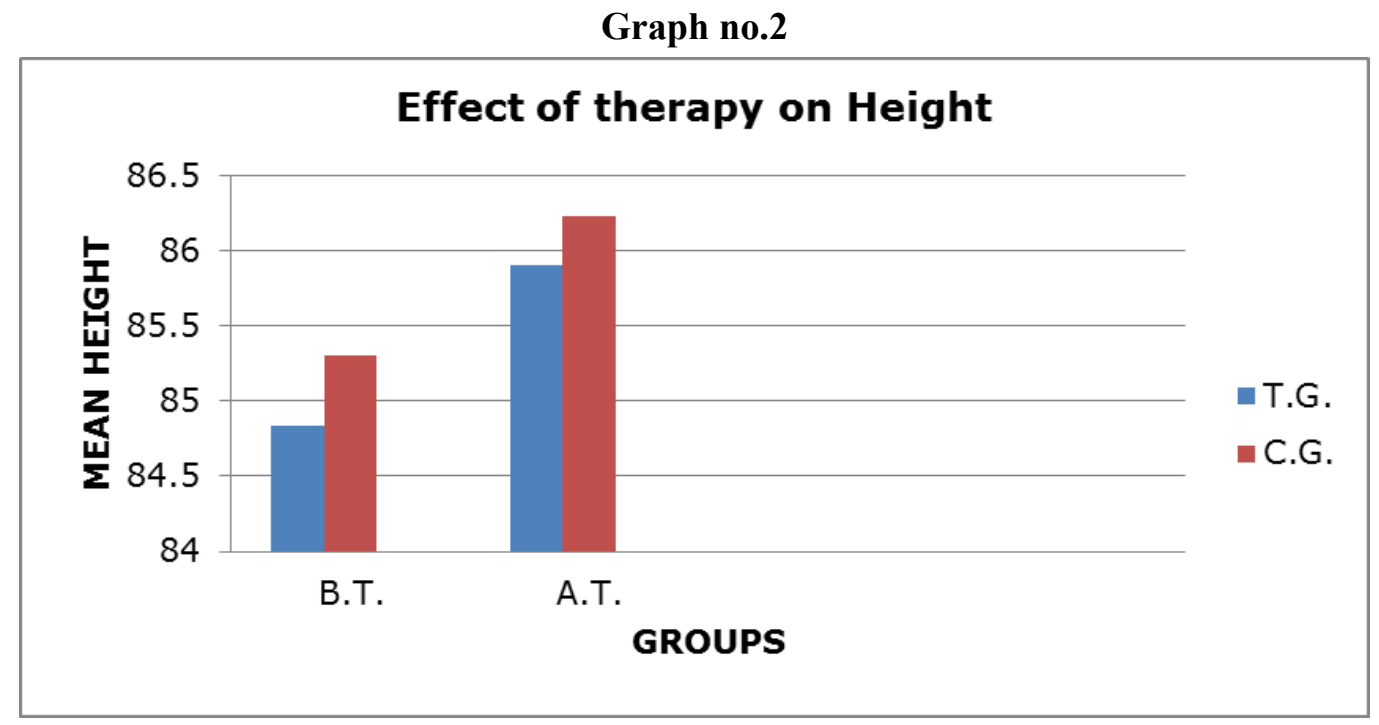

Graph no.3

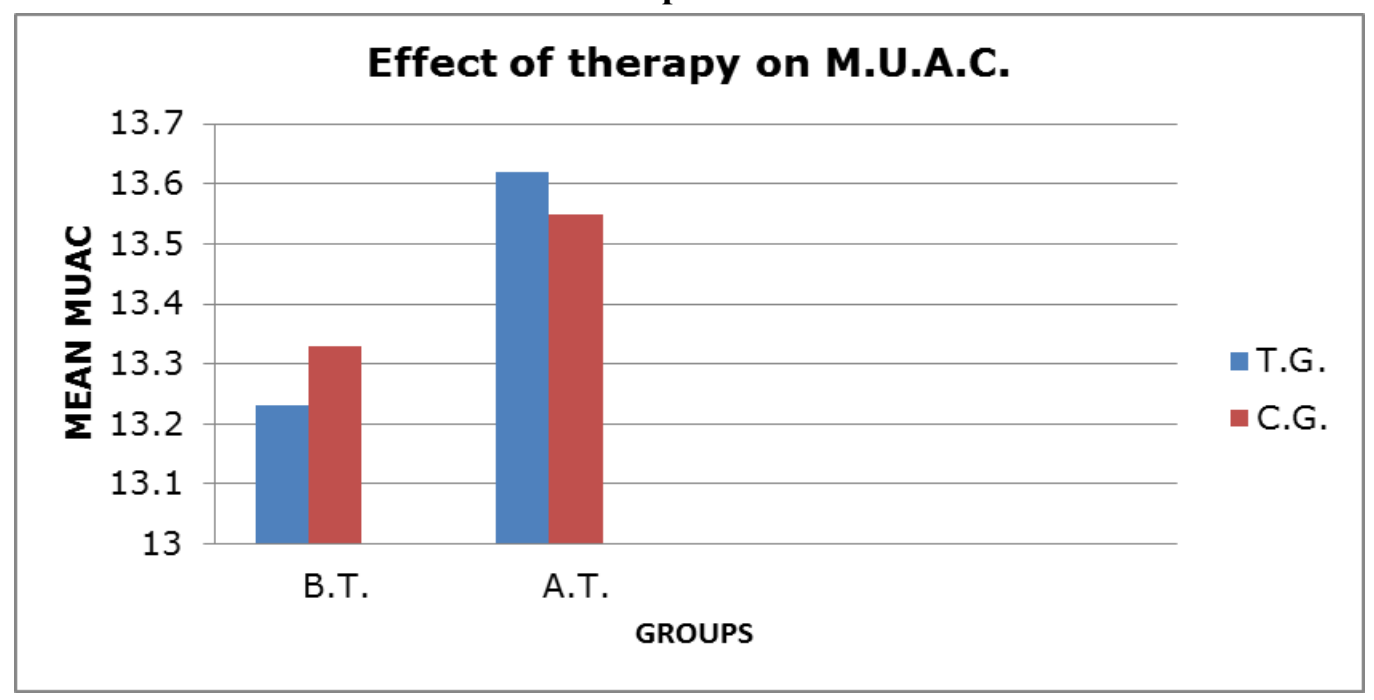

Graph no.4

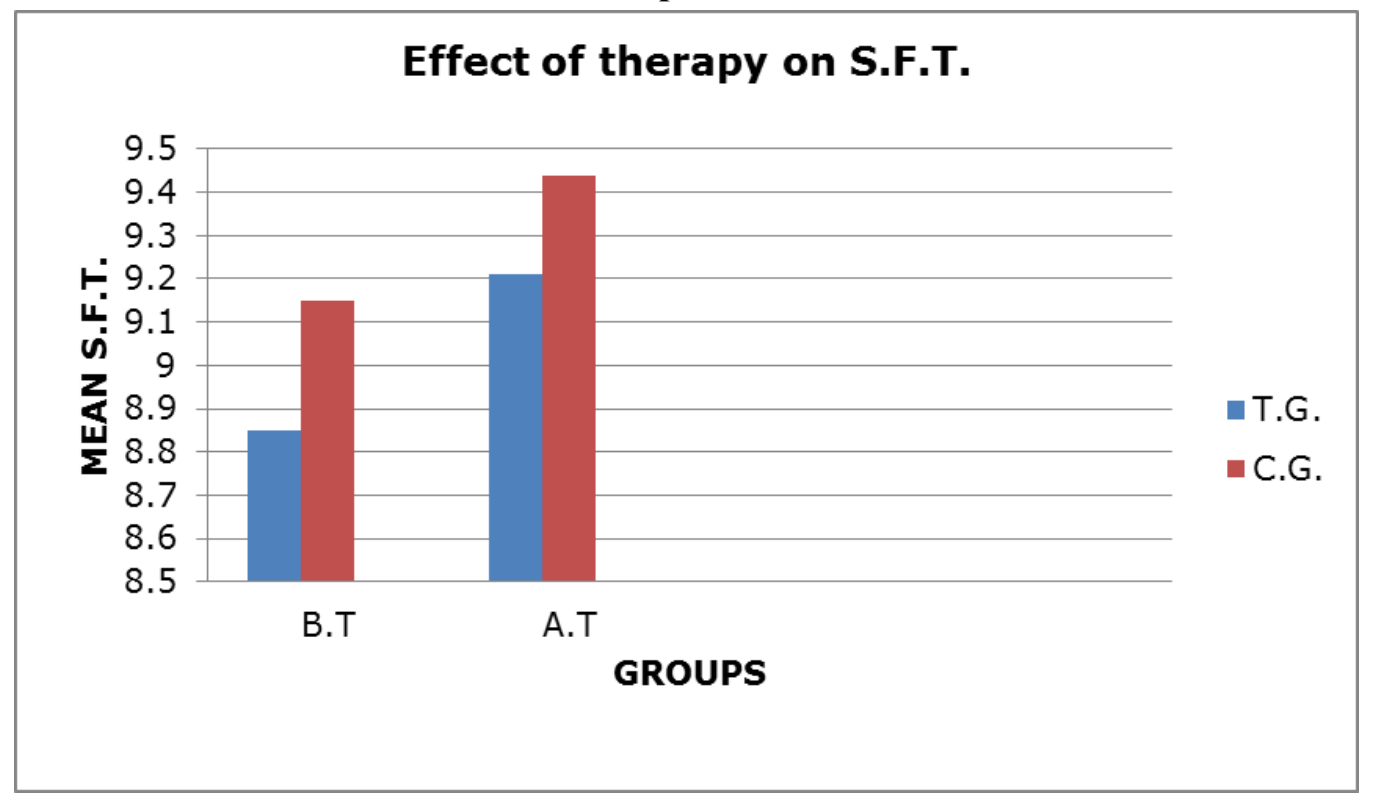


Graph no.5

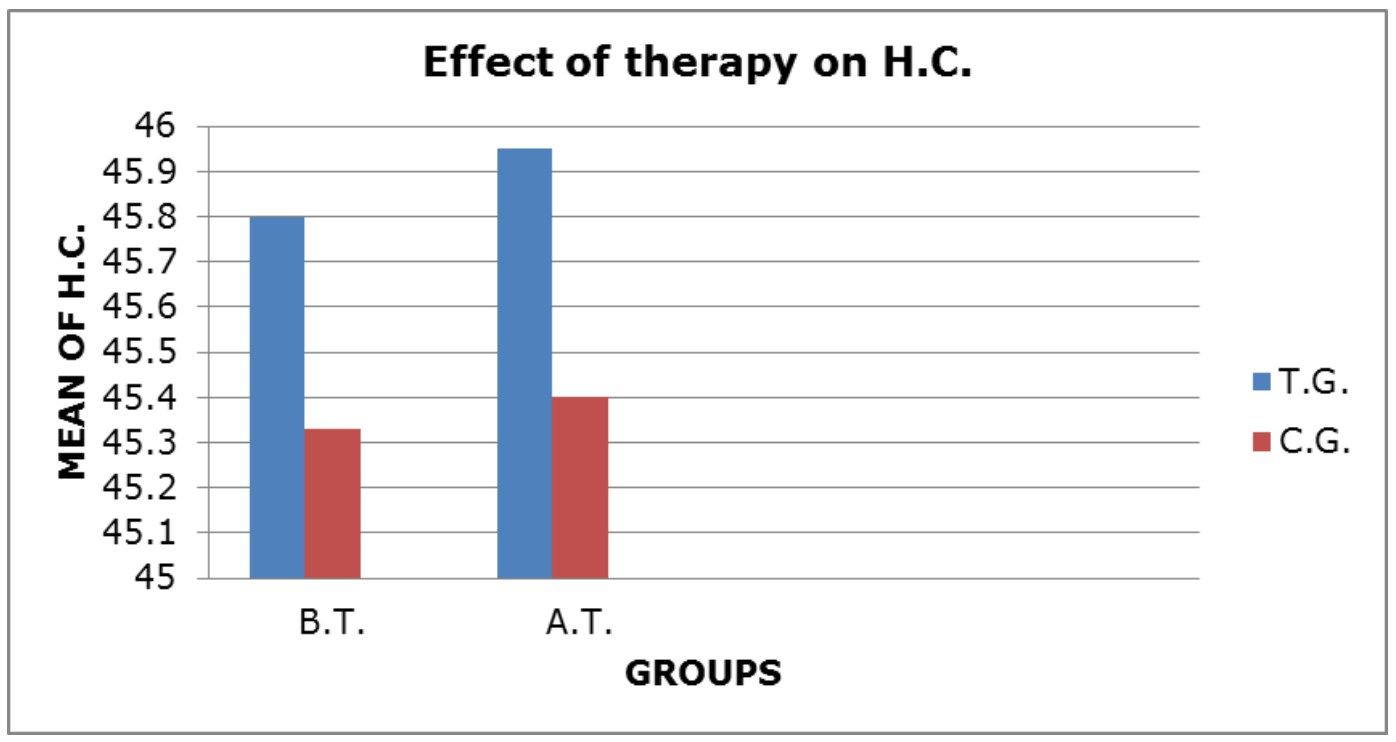

Graph no.6

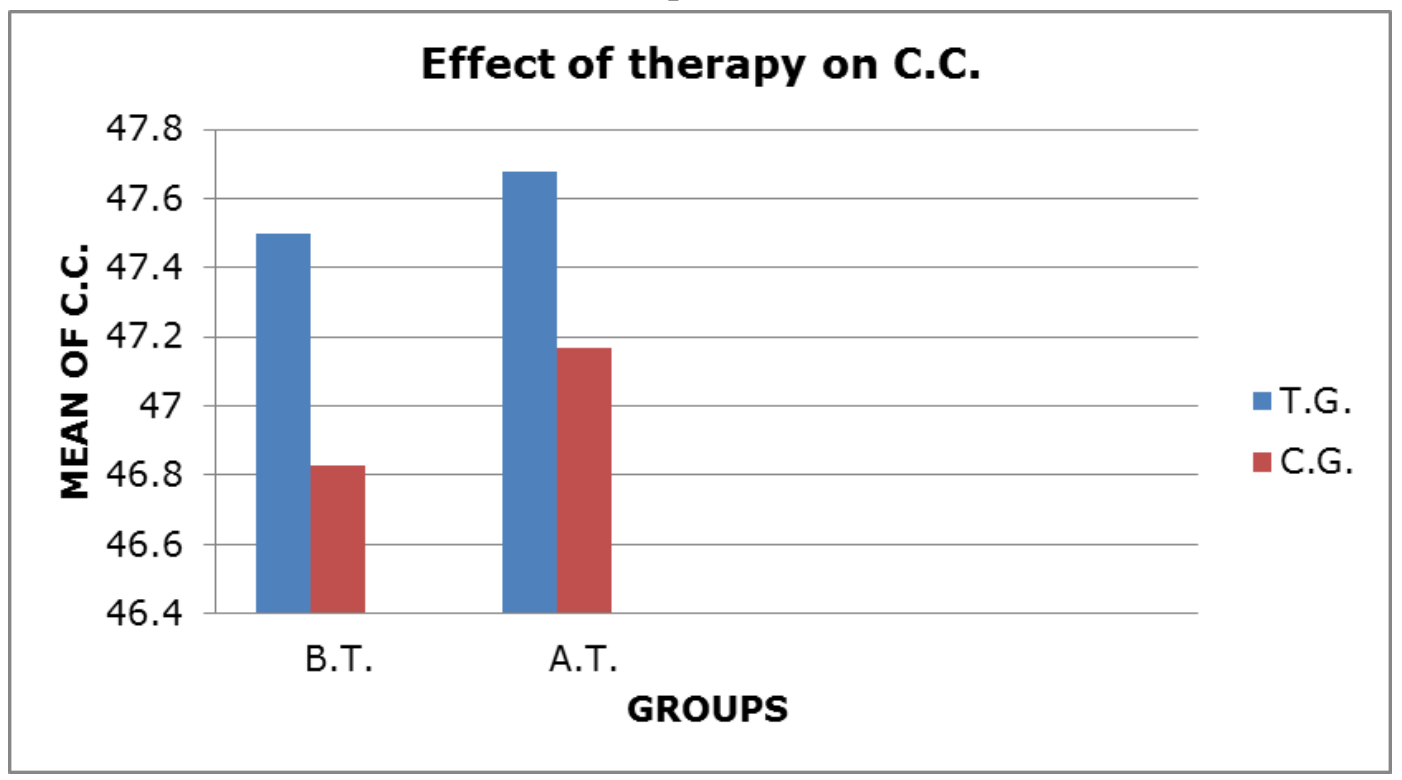

Graph no.7

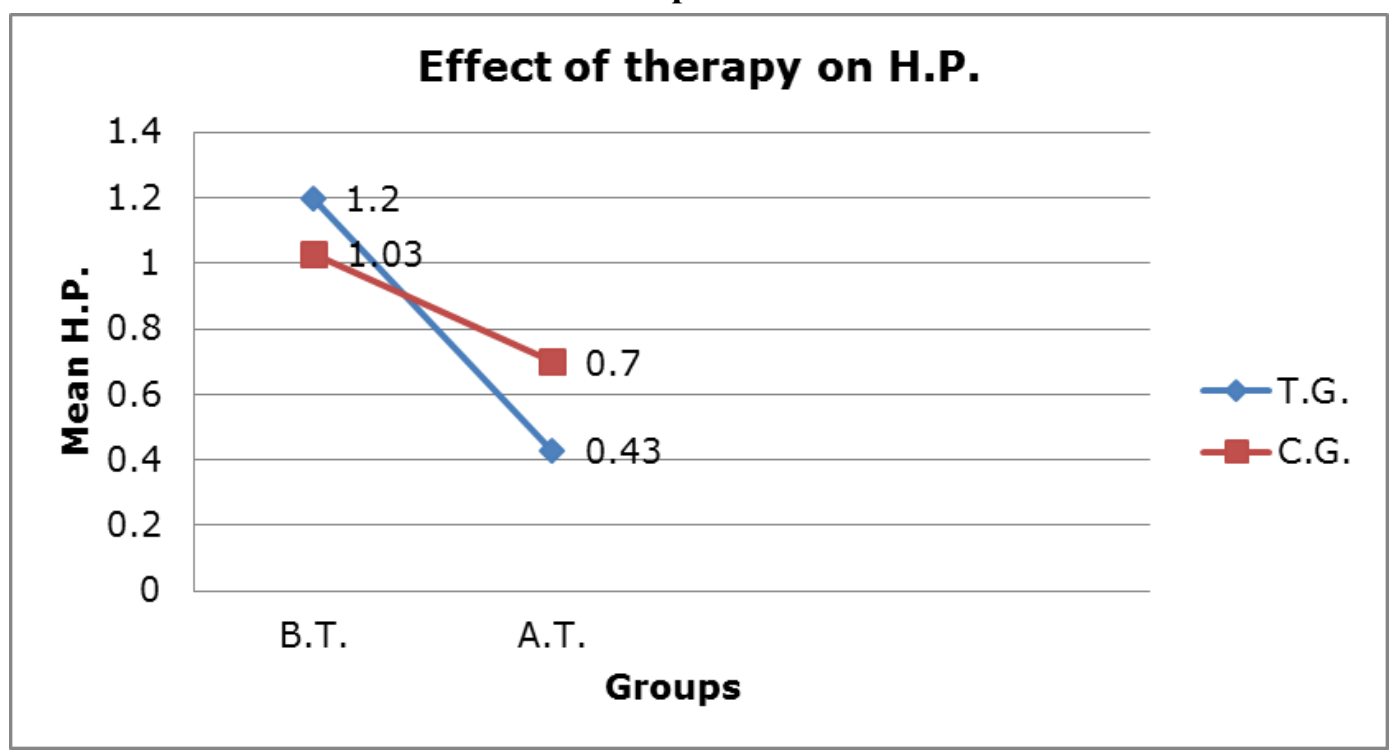




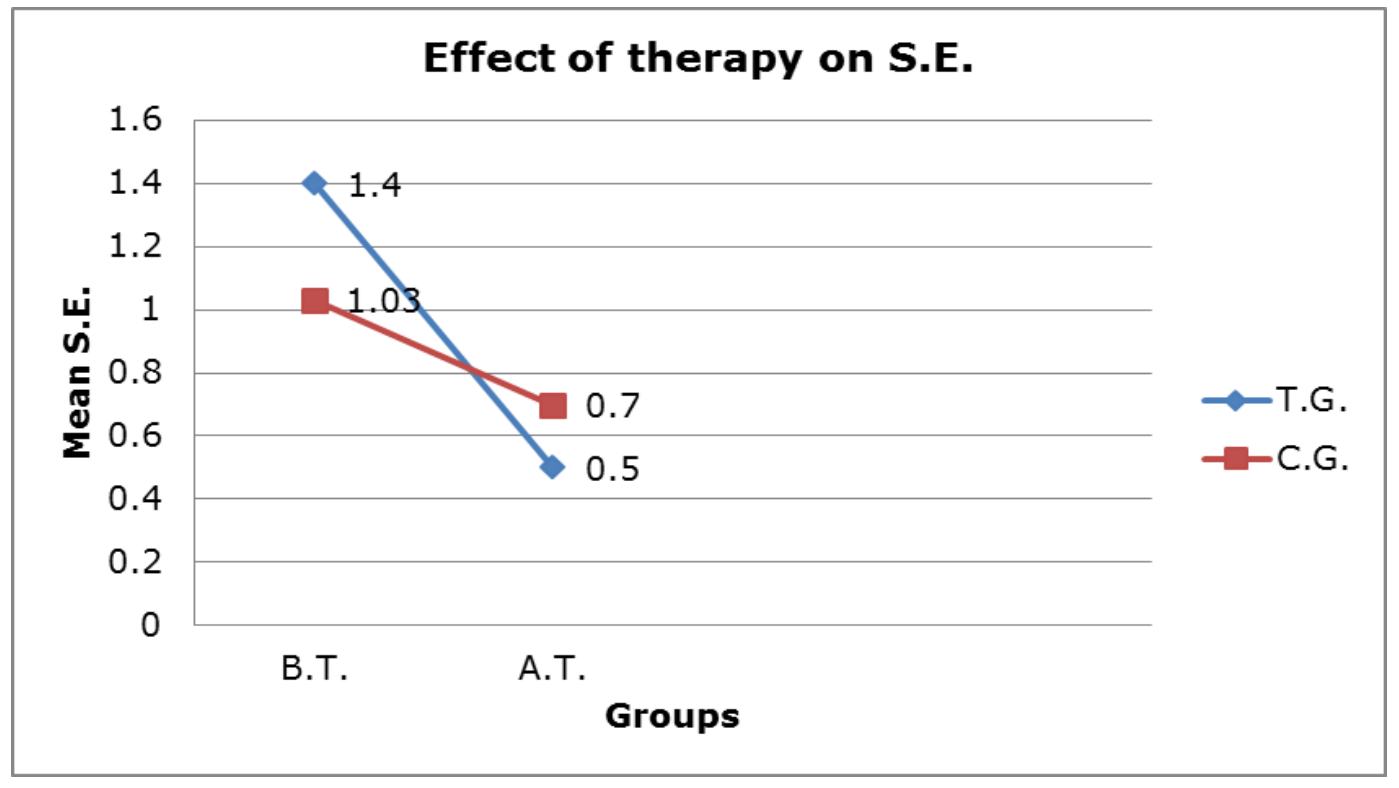

Graph no.9

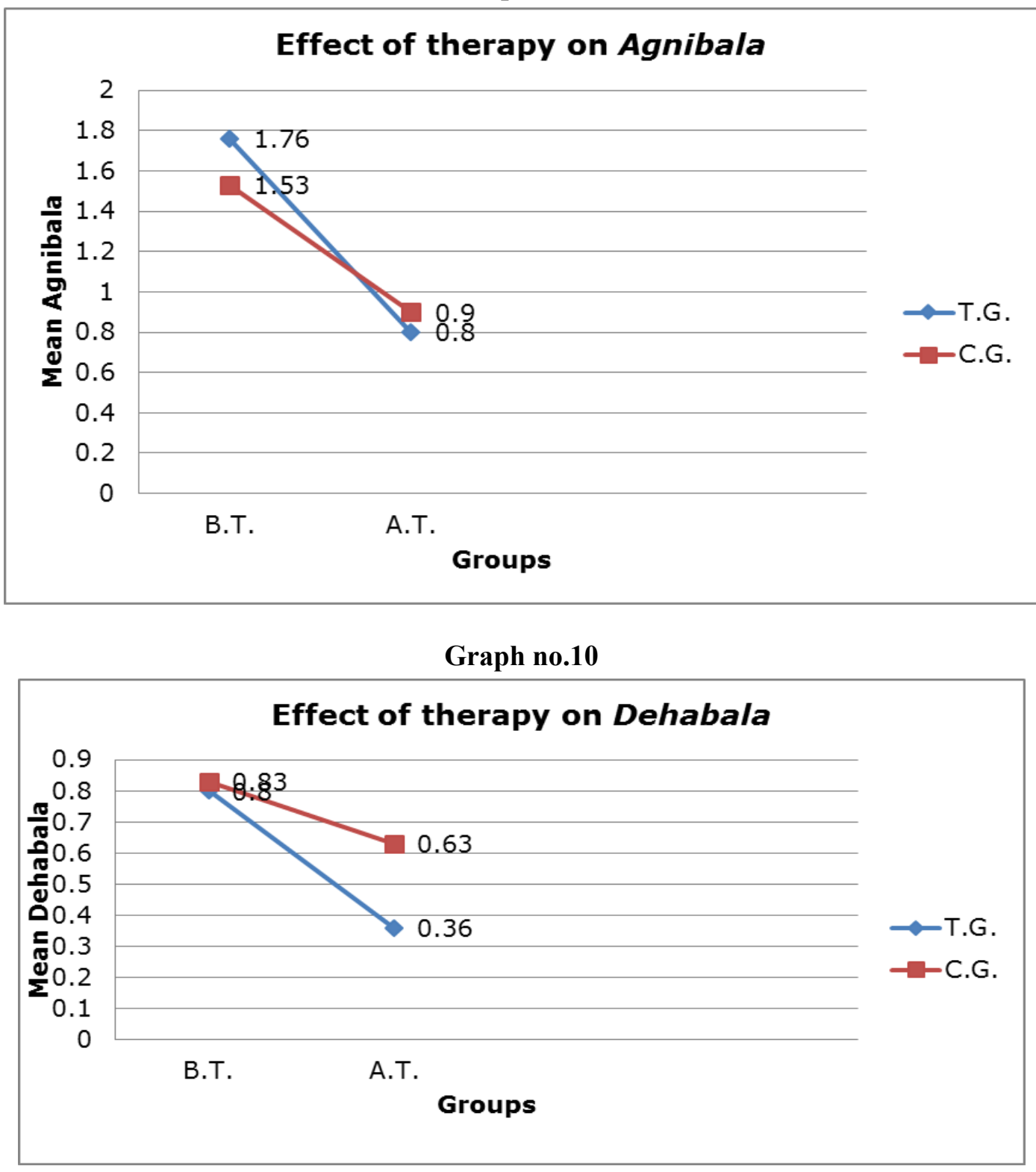


Graph no.11

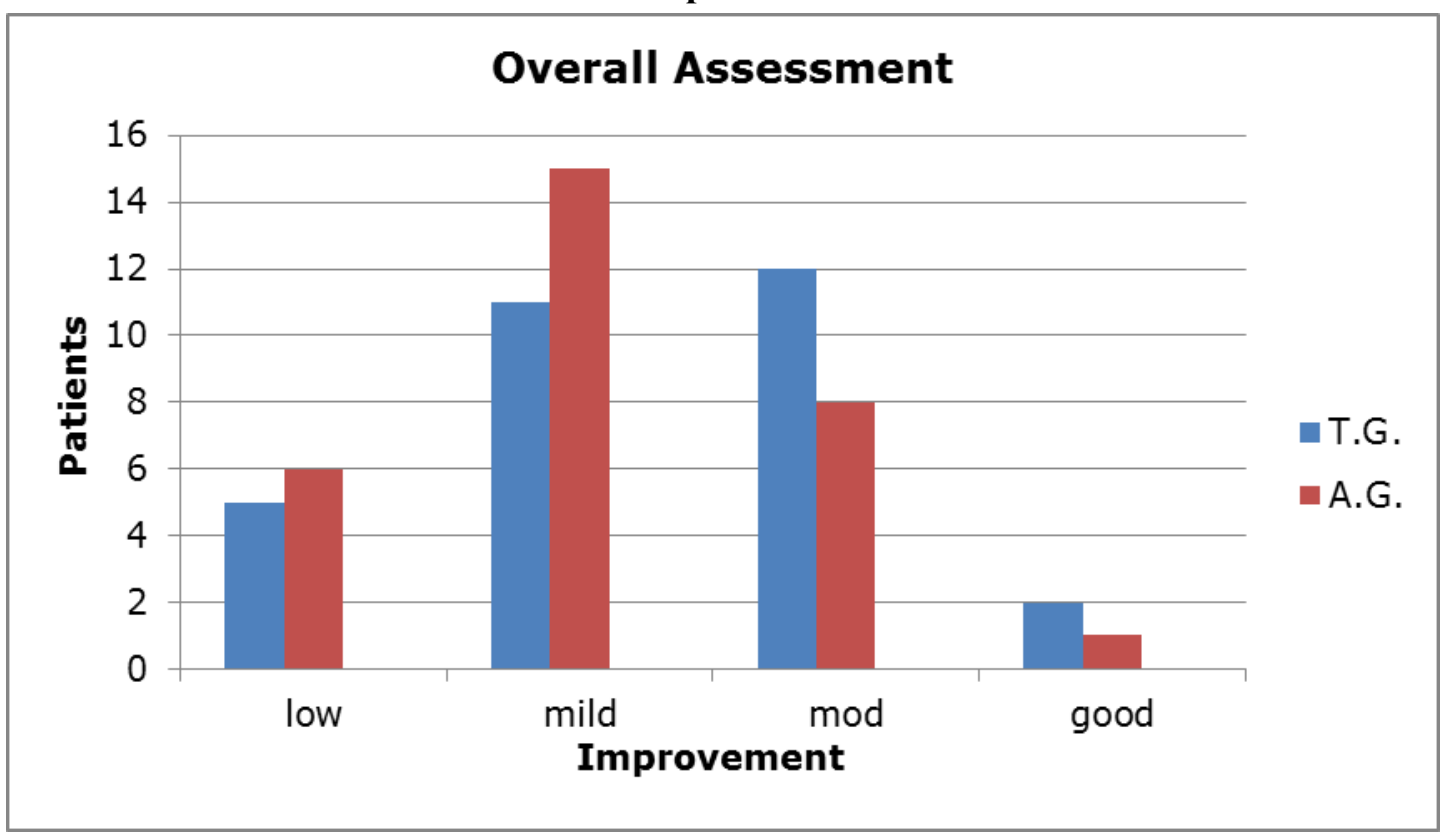

$* * * * *$ 